\title{
Efektivitas Pemanfaatan Komik sebagai Media Pembelajaran Matematika
}

\author{
Erlanda Nathasia Subroto ${ }^{1}$, Abd. Qohar ${ }^{1}$, Dwiyana ${ }^{1}$ \\ ${ }^{1}$ Pendidikan Matematika-Universitas Negeri Malang
}

\begin{tabular}{l} 
INFO ARTIKEL \\
\hline Riwayat Artikel: \\
Diterima: $24-06-2019$ \\
Disetujui: $10-02-2020$ \\
\hline
\end{tabular}

Kata kunci:

comics;

mathematics;

learning media;

komik;

matematika:

media pembelajaran

\author{
Alamat Korespondensi: \\ Erlanda Nathasia Subroto \\ Pendidikan Matematika \\ Universitas Negeri Malang \\ Jalan Semarang 5 Malang \\ E-mail: erlanda2294@gmail.com
}

\begin{abstract}
ABSTRAK
Abstract: This study aims to determine the effectiveness of the use of comics as a media in mathematics learning. This research was conducted in home schooling "Sekolah Dolan" Malang with research subjects is students of class VII. The data collection of this study uses questionnaire about media selection, questionnaires about student response and unstructured interviews. The percentage of the results media selection questionnaire obtained as much as $55 \%$ of students chose to use comics as learning media and the percentage of student responses questionnaires obtained $88.58 \%$ responses of students are positive to use comics. Based on the assessment category, it was concluded that comics were effectively used as learning media. This is because comics contain many colors and images and when changing learning material into comics, the material will become easier because the material is delivered in the daily conversation.
\end{abstract}

\begin{abstract}
Abstrak: Penelitian ini bertujuan untuk mengetahui efektivitas pemanfaatan komik sebagai media dalam pembelajaran Matematika. Penelitian ini dilakukan di Homeschooling "Sekolah Dolan" Malang dengan subjek penelitian siswa kelas VII. Pengumpulan data penelitian ini menggunakan angket pemilihan media, angket respon siswa dan wawancara tidak terstruktur. Persentase hasil data angket pemilihan media diperoleh sebanyak 55\% siswa memilih menggunakan komik sebagai media pembelajaran dan persentase hasil angket respon siswa diperoleh $88,58 \%$ respons siswa positif terhadap penggunaan komik. Berdasarkan kategori penilaian, maka disimpulkan bahwa komik efektif digunakan sebagai media pembelajaran. Hal tersebut dikarenakan komik memuat banyak warna dan gambar serta apabila mengubah materi pembelajaran ke dalam komik, maka materi akan menjadi lebih mudah karena materi disampaikan dalam bentuk percakapan sehari-hari.
\end{abstract}

Komik merupakan kumpulan gambar yang disusun dalam suatu urutan yang terangkai dalam bingkai serta mengungkapkan karakter yang dikemas dalam cerita untuk meningkatkan daya imajinasi pembaca (Negara, 2014). Komik juga diartikan sebagai bentuk kartun yang memuat karakter untuk memerankan suatu cerita dalam urutan tertentu. Pada umumnya, komik dihubungkan dengan suatu gambar yang dirancang untuk memberikan hiburan kepada pembacanya (Sudjana \& Rivai, 2010). Komik memiliki beberapa karakteristik, di antaranya (Sudjana \& Rivai, 2010): (a) komik biasanya terdiri dari berbagai situasi cerita yang bersambung; (b) bersifat menghibur; (c) apabila komik memiliki perwatakan lain, biasanya dikenal agar kekuatan komik dapat dihayati; (d) komik memusatkan perhatian di lingkungan sekitar rakyat; (e) pembaca dapat dengan segera mengidentifikasi dirinya melalui perasaan serta tindakan dari perwatakan tokoh utama karena cerita pada komik mengenai diri pribadi; (f) cerita dalam komik ringkas dan menarik perhatian; (g) komik biasanya dilengkapi aksi; (h) pembuatannya lebih hidup dengan pemakaian warna utama secara bebas.

Di masa sekarang beberapa pendidik melihat komik sebagai suatu alat yang dapat digunakan sebagai literasi siswa karena pendidik telah menggunakan komik di kelas selama lebih dari 60 tahun (Hosler \& Boomer, 2011). Pendidik juga mulai menyadari kekuatan dari media komik dengan memasukkan komik ke dalam praktik mengajarnya (Pelton, 2015). Wright \& Sherman (2006) berpendapat bahwa komik memiliki daya tarik tertentu pada anak-anak usia sekolah, karena pada umumnya siswa merasa nyaman dalam menggabungkan informasi dalam bentuk visual dan teks yang ada pada komik. Secara tradisional, komik pada umumnya memiliki beberapa pesan untuk anak-anak, seperti solidaritas, persahabatan, kejujuran, dan sebagainya (Özdemir, 2010). Anak-anak juga sering memilih sastra komik daripada teks tradisional karena komik menawarkan visual, gambar dan seni lainnya bersamaan dengan kata-kata dan dialog. Semua hal tersebut membuat teks bukan hanya untuk dibaca, 
namun dilihat seperti membaca dan menonton film secara bersamaan (Weiner, 2004). Selain itu, anak-anak usia sekolah juga menyukai komik karena dengan mengidentifikasi karakter dalam komik, anak-anak mendapatkan kesempatan mengenal masalah pribadi maupun sosial sehingga membantunya dalam memecahkan masalahnya sendiri (Karmawati, 2007).

Dalam pendidikan, komik juga telah dianggap sebagai sumber pedagogis yang penting (Santana \& Arro10, 2012). Hal tersebut dikarenakan apabila dieksplorasikan di dalam kelas dengan baik, komik dengan fiturnya yang khas memiliki kekuatan besar untuk: menceritakan suatu kisah dan menyampaikan pesan, berkontribusi dalam merangsang partisipasi aktif dan kreativitas siswa (Gafoor \& Shilna, 2013; Weber et. al, 2013), pengembangan kemampuan teknologi (Weber et. al, 2013), digunakan sebagai cara dalam meningkatkan minat belajar siswa (Sones, 1944; Cleaver, 2008; Sudjana \& Rivai, 2010; Mediawati, 2011; Yunus, Salehi \& Embi, 2012; Septy, Yusuf, \& Aisyah, 2014; Buchori \& Setyawati, 2015; Arini, Choiri \& Sunardi, 2017; Widyastuti, Mardiyana \& Saputro, 2017), dengan adanya komik siswa lebih menjadi termotivasi (Smith, 2006; Toh, 2009; Buchori \& Setyawati, 2015), memiliki kemampuan dalam memenuhi kebutuhan siswa secara akademik (Thacker, 2007), dalam penggunaannya membuat siswa lebih tertantang dalam mengerjakan tugas (Reilly, 2014), serta sebagai mekanisme memperkenalkan topik maupun sebagai sumber daya untuk memberikan informasi maupun dukungan kegiatan belajar lainnya (Pelton, 2015). Komik juga merupakan suatu alat pengajaran yang sangat efektif, karena komik menggabungkan dua bentuk ekspresi budaya, yaitu sastra dan seni (Özdemir, 2010). Selain itu, komik dapat dibuat dan langsung digunakan dalam mengajarkan konsep tertentu (Özdemir, 2010). Rota \& Izquierdo (2003) membuat dan menggunakan komik secara langsung untuk mengajarkan konsep bioteknologi di tingkat sekolah dasar. Demikian pula, Olson (2008) membuat dan menggunakan komik strip di kelas sains sebagai metode pengajaran untuk mempromosikan literasi sains. Dalam studinya, komik strip tersebut diimplementasikan dalam kelas sains sebagai kegiatan pembelajaran untuk membaca, berpikir, dan berdiskusi. Hasil penelitiannya menunjukkan bahwa siswa menganggap komik lucu dan efektif jika digunakan dalam belajar. Penelitian lain yang dilakukan Cheesman (2006), komik membantu siswa untuk fokus pada pelajaran dan belajar berpikir dengan cara yang kritis.

Menurut Yang Gene (2003), dalam pendidikan komik memiliki beberapa kekuatan, di antaranya (a) motivasi sesuai dengan daya tarik alami manusia terhadap gambar sehingga komik dapat menangkap dan mempertahankan minat siswa; (b) Visual. Hal tersebut dikarenakan gambar dan teks saling menceritakan sebuah kisah. Dalam "interplay of the written and visual" komik menghasilkan hubungan emosional antara siswa dan karakter dari cerita komik (Versaci, 2001); (c) Permanen. Williams (1995) menyatakan komik berbeda dengan film dan animasi yang menentukan laju penayangan berlangsung. Sedangkan waktu komik berlangsung pada kecepatan pembaca; (d) Perantara. Komik dapat memberikan scaffold terhadap konsep yang sulit; (e) Populer. Buku komik mempromosikan literasi media, mendorong siswa untuk menjadi konsumen kritis pesan media (Morrison, Bryan, \& Chilcoat, 2002). Selain itu, melalui buku komik tentang aspek sosial, siswa dapat memeriksa gaya hidup saat ini, mitos, maupun nilai-nilai; (f) Mengembangkan kemampuan berpikir. Kemampuan berpikir analitis dan kritis dapat dikembangkan melalui komik (Versaci, 2001).

Media komik dapat digunakan sebagai salah satu media pembelajaran dalam pendidikan apabila media komik dirancang sesuai dengan kebutuhan siswa dan disesuaikan dengan materi yang akan disampaikan (Budiarti \& Haryanto, 2016), misalnya pada pembelajaran Matematika. Media komik pada pembelajaran Matematika merupakan alat bantu yang berupa cerita dengan menggunakan rangkaian gambar tidak bergerak serta divisualisasikan dalam kotak-kotak serta balon-balon percakapan yang memuat simbol-simbol tertentu untuk menyampaikan pesan yang berisi permasalahan dalam Matematika (Manalu, Hartono \& Aisyah, 2017). Penyajian pelajaran Matematika dalam bentuk komik, dapat membantu siswa melancarkan membaca, serta dapat mengurangi rasa bosan siswa terhadap Matematika (Karmawati, 2007).

Indaryati \& Jailani (2015) memanfaatkan komik sebagai suatu media pembelajaran. Dalam jurnal yang ditulisnya, pembelajaran Matematika dengan menggunakan media komik pembelajaran, memberikan bukti secara efektif untuk meningkatkan motivasi yang dimiliki siswa dan dan prestasi terhadap materi yang dipelajari. Selain itu, Budiarti \& Haryanti (2016) juga menggunakan komik sebagai media pembelajaran. Dalam jurnal yang ditulisnya, media komik memberikan pengaruh positif terhadap motivasi belajar dan keterampilan membaca siswa. Kesamaan dua jurnal tersebut adalah keduanya menggunakan media komik sebagai media untuk meningkatkan motivasi siswa, namun tidak melihat kegunaan media komik dalam membantu siswa memahami materi pembelajaran. Berdasarkan uraian yang telah dipaparkan, maka selanjutnya dilakukan penelitian yang bertujuan untuk mengetahui penggunaan komik dalam pembelajaran Matematika apakah membantu siswa dalam mempelajari serta memahami konsep yang sulit. Penelitian ini dilakukan juga untuk melihat apakah pembelajaran dengan menggunakan komik tidak membuat siswa semakin merasa kesulitan dalam belajar Matematika karena materi akan diubah ke dalam bentuk percakapan.

\section{METODE}

Penelitian ini dilaksanakan di homeschooling "Sekolah Dolan" Malang yang bertempat di Villa Bukit Tidar A2 No. 156. Pada penelitian ini, teknik pengumpulan data yang digunakan yaitu angket dan wawancara tidak terstruktur. Data angket didapatkan dari angket pemilihan media pembelajaran yang disebarkan kepada siswa kelas VII. Untuk menganalisis angket pemilihan media pembelajaran dapat menggunakan teknik analisis data sebagai berikut (Sutrisno, 2016). 


$$
p=\frac{m_{i}}{N} \times 100 \%
$$

Keterangan:

$p$ : persentase; $m$ : banyak siswa yang memilih media ke-i; $N$ : jumlah siswa

Selain itu, terdapat pula angket respon untuk menilai respon siswa dalam penggunaan media yang telah dipilih. Setelah angket telah diisi, selanjutnya angket tersebut dianalisis dengan teknik persentase sehingga diperoleh hasil respons siswa. Untuk menganalisis angket respon siswa dapat menggunakan teknik analisis data sebagai berikut (Sutrisno, 2016):

Keterangan:

$$
p=\frac{f}{n} \times 100 \%
$$

$p$ : persentase; $f$ : frekuensi jawaban; $n$ : jumlah skor maksimal

Perhitungan tersebut dilakukan untuk menilai dari setiap aspek yang termuat pada lembar angket yang diberikan kepada siswa. Perhitungan tersebut mengacu pula pada kriteria yang ditentukan sesuai pada tabel 1.

Tabel 1. Pedoman Kriteria Persentase

\begin{tabular}{lcl}
\hline \multicolumn{1}{c}{ Kategori } & Persentase & \multicolumn{1}{c}{ Keterangan } \\
\hline Efektif & $\geq 50 \%$ & Komik efektif digunakan sebagai media pembelajaran Matematika \\
Tidak Efektif & $<50 \%$ & Komik tidak efektif digunakan sebagai media pembelajaran Matematika \\
\hline
\end{tabular}

\section{HASIL}

Berdasarkan wawancara yang dilakukan peneliti berkaitan dengan penggunaan media di sekolah didapatkan bahwa selama ini guru mata pelajaran Matematika yang mengajar komunitas hanya menggunakan modul yang diberikan dari sekolah. Pada pembelajarannya, guru Matematika juga kurang memanfaatkan media sehingga ketika penelitian berlangsung, siswa merasa sangat senang, bersemangat dan tertarik ketika menggunakan komik. Berikut contoh modul yang digunakan (Tabel 1).

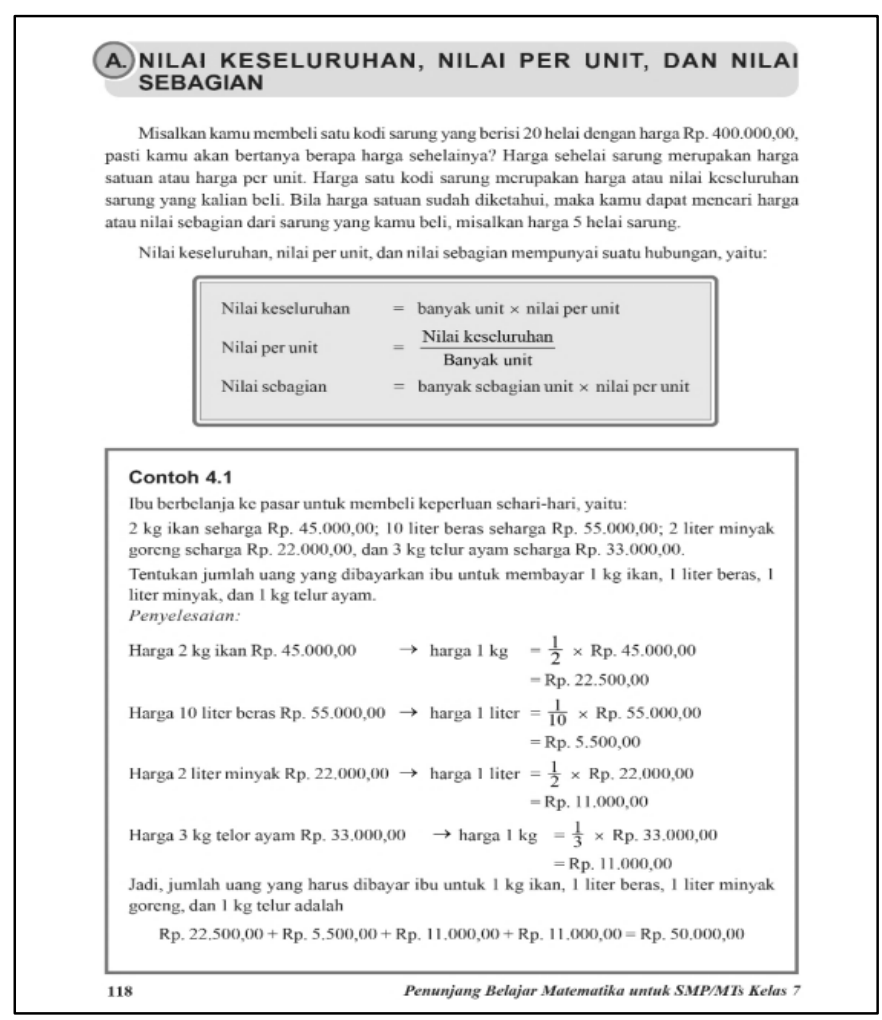

Gambar 1. Modul penunjang belajar yang digunakan di homeschooling "Sekolah Dolan" 
Berdasarkan modul penunjang belajar tersebut, dapat diketahui bahwa buku Matematika disajikan dalam bentuk pada umumnya yaitu hanya memuat teks berwarna hitam putih. Penggunaan kalimat pada buku penunjang tersebut juga membuat siswa sulit memahami inti materi karena kalimat tidak menggunakan kalimat sehari-hari yang lebih dimengerti oleh siswa. Selain itu, pada hasil wawancara berkaitan dengan modul yang digunakan pada pembelajaran didapatkan banyak siswa merasa bosan dan tidak tertarik untuk sekedar membuka modul tersebut karena tidak adanya warna dan gambar didalamnya. Selanjutnya, diberikan angket kepada seluruh siswa SMP yang ada di komunitas tersebut berkaitan dengan penggunaan media yang diinginkan siswa dalam pembelajaran Matematika dan didapatkan hasil sebagaimana ditunjukkan pada gambar 2.

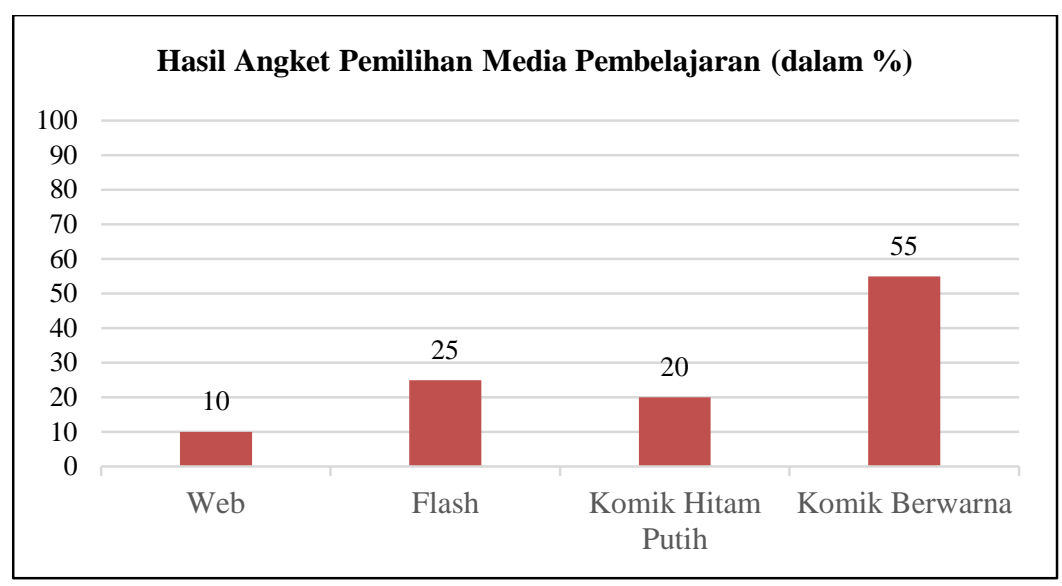

\section{Gambar 2. Persentase Pemilihan Media Pembelajaran}

Berdasarkan grafik tersebut, maka dapat dikatakan bahwa persentase siswa yang memilih web sebesar $10 \%$, untuk siswa yang memilih flash sebesar 25\%, untuk siswa yang memilih komik hitam putih sebesar $20 \%$ dan siswa yang memilih komik berwarna sebagai media pembelajaran sebesar 55\%. Maka, dapat disimpulkan bahwa siswa memilih komik berwarna sebagai media pembelajaran.

Selanjutnya, sebagai tindak lanjut dari hasil pemilihan media pembelajaran, maka langkah selanjutnya yaitu diadakannya komik dengan materi Aritmatika Sosial. Pemilihan materi aritmatika sosial tersebut berdasarkan wawancara tidak terstruktur yang dilakukan kepada siswa mengenai materi dalam Matematika yang dianggap paling sulit. Setelah memilih materi, selanjutnya proses pembuatan komik Aritmatika Sosial. Berikut ini merupakan gambar komik yang telah dibuat:
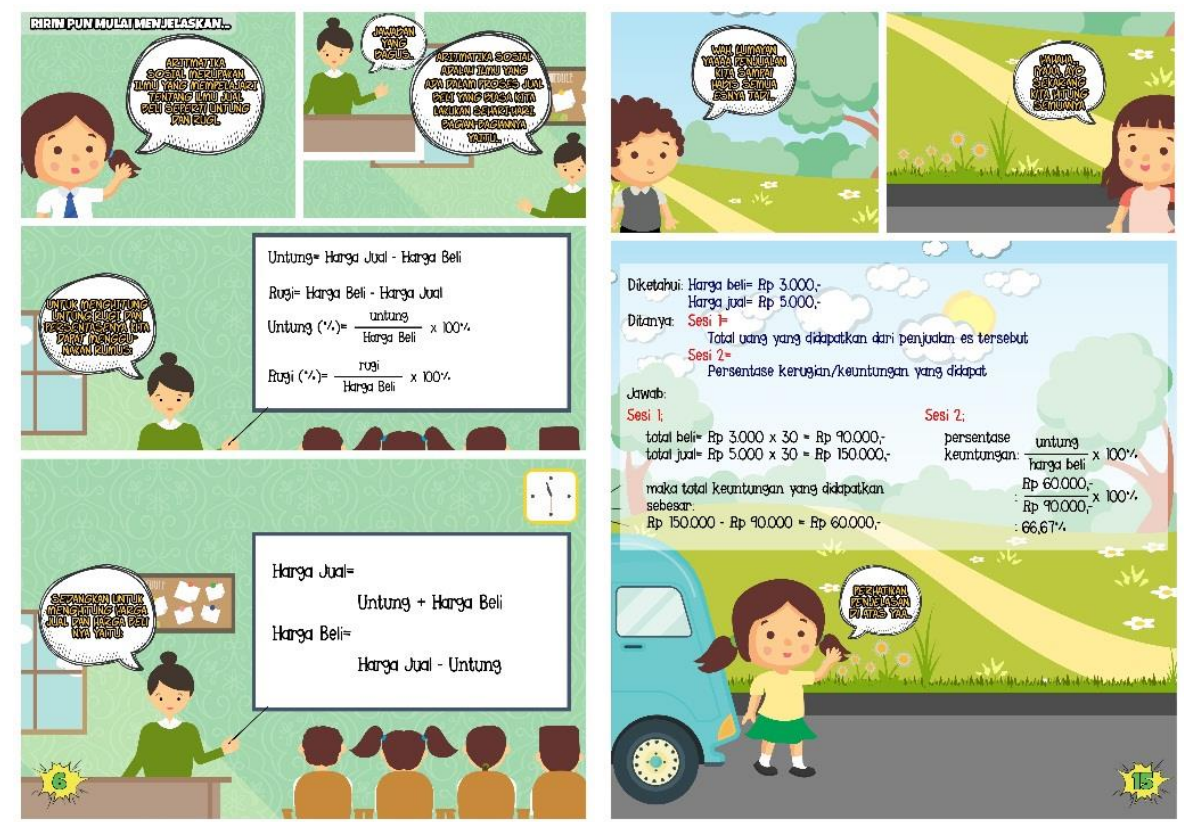

Gambar 3. Komik Aritmatika Sosial 
Setelah pembelajaran menggunakan komik, selanjutnya disebarkan angket respon siswa yang digunakan untuk menilai komik yang diberikan. Berikut merupakan hasil yang didapatkan:

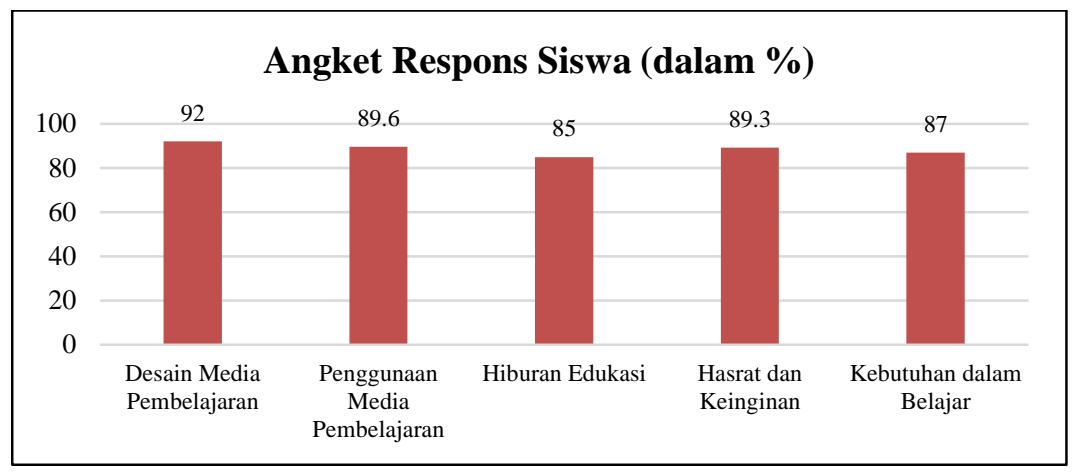

\section{Gambar 3. Hasil angket respons siswa mengenai komik dalam pembelajaran Matematika}

Berdasarkan grafik diatas, maka kesimpulan yang didapatkan adalah respon siswa terhadap media komik yang digunakannya rata-rata keseluruhannya adalah 88,58\%. Berdasarkan tabel 1 pedoman kriteria, rata-rata persentase siswa berada pada kategori efektif digunakan dalam pembelajaran Matematika. Selain itu, dari penyebaran angket tersebut siswa (D) memberikan pendapatnya bahwa dengan menggunakan komik, siswa merasa sangat senang, bersemangat, dan tertarik mengikuti pembelajaran Matematika. Respon siswa lainnya, siswa (F) menyukai adanya komik sebagai media pembelajaran karena memuat banyak gambar dan banyak warna sehingga Matematika menarik untuk dipelajari. Serta siswa (G) berpendapat bahwa karena materi Matematika diubah ke dalam bentuk kalimat sehari-hari maka hal itu berdampak pada Matematika yang menjadi lebih mudah dipahami dan dimengerti.

\section{PEMBAHASAN}

Komik sebagai media pembelajaran dapat menarik perhatian siswa karena pemakaian gambar kartun di dalamnya serta memuat halaman yang berwarna warni. Hasil penelitian serupa menyatakan bahwa komik digambarkan sebagai hal yang menyenangkan (Karmawati, 2007; Hadi, 2008; Graham, 2011, Manalu, Hartono \& Aisyah, 2017). Pemakaian gambar kartun pada komik dapat memberikan dampak positif terhadap respon siswa. Hal tersebut dikarenakan gambar pada media komik menekankan pada kejelasan gambarnya, pada pewarnaan yang kontras, pada ketelitian dalam pemakaian bahasa, dan pada ketersambungan antara penggunaan kalimat dengan ilustrasi gambar (Novianti \& Syaichudin, 2010). Hal tersebut sesuai dengan penelitian yang dilakukan oleh Keogh and Naylor (1999) yang juga menggunakan konsep kartun dalam memperluas jangkauan strategi pedagogis serta menyajikan rangkaian gagasan alternatif suatu konsep ilmiah dalam bentuk visual. Dalam penggunaannya, Keogh dan Naylor menggunakan kartun di kelas untuk mendukung pembelajaran dengan mengadakan suatu diskusi, merangsang penyelidikan, dan mengembangkan keterlibatan serta motivasi siswa. Penggunaan warna dalam pembelajaran juga memberikan dampak tersendiri karena adanya warna mampu memberikan pengaruh yang positif dalam meningkatkan kemampuan mengingat yang dimiliki siswa dalam belajar (Sujarwo \& Oktaviana, 2017). Komik dalam pembelajaran juga berperan sebagai alat yang menyampaikan pesan pembelajaran (Waluyanto, 2005). Hal tersebut dikarenakan komik membantu belajar konsep yang sulit maupun mempermudah mengingat materi pelajaran yang dipelajari siswa (Mediawati, 2011; Yunus, Salehi \& Embi, 2012; Monnin, 2012). Penggunaan komik tersebut memudahkan siswa karena materi Matematika yang pada umumnya diberikan secara monoton diubah menjadi kalimat percakapan yang lebih dipahami oleh siswa. Hal tersebut sesuai dengan pernyataan Widyastuti, Mardiyana and Saputro (2017) bahwa komik merupakan gambar yang memiliki alur cerita yang menarik, yang mudah dimengerti, dan dapat membuat mereka mudah memahami materi yang sulit.

Kepentingan dalam membaca komik, terkhusus media komik pembelajaran oleh Vulte (2014) yang menyatakan alasan perlunya membaca komik, di antaranya (a) kalimat-kalimat yang termuat didalam komik memiliki kata-kata yang lebih kompleks dibandingkan dengan media cetak lainnya; (b) komik telah dianggap dapat meningkatkan daya ingat. Hal tersebut dikarenakan komik dibuat secara berurutan, membutuhkan daya ingat dan imajinasi oleh diri sendiri; (c) dalam pengenalannya, komik mengenalkan cerita yang tidak biasa; (d) komik dianggap menjadi suatu cara dalam mempelajari sastra yang rumit dan banyak jenisnya namun mudah untuk dimengerti; (e) komik dapat digunakan sebagai pembelajaran karakter karena apabila komik disajikan bersifat brutal dan kasar maka anak yang membaca akan bertindak seperti yang dibacanya (Karmawati, 2007); f) komik dapat memudahkan pembaca terhadap pemahaman isi bacaan; (g) komik dapat menciptakan semangat dalam menulis, karena anak-anak senang berimajinasi; (h) dapat menambah pengetahuan tentang kata-kata baru; (i) digunakan sebagai bahan perluasan imajinasi yang dimiliki; (j) komik dapat digunakan sebagai meningkatkan prestasi (Budiarti \& Haryanto, 2016). Maka berdasarkan uraian tersebut, dapat disimpulkan komik memiliki efektivitas apabila digunakan sebagai media dalam pembelajaran Matematika. 


\section{SIMPULAN}

Berdasarkan perhitungan analisis yang dilakukan didapatkan disimpulkan komik efektif merupakan media pembelajaran yang efektif apabila digunakan dalam pelajaran Matematika. Selain itu, siswa berpendapat bahwa dengan menggunakan komik, Matematika menjadi pelajaran yang menyenangkan. Siswa juga bersemangat dan tertarik mengikuti pembelajaran. Pendapat lain, siswa menyukai komik sebagai salah satu media dalam pembelajaran Matematika karena adanya banyak warna dan gambar di dalamnya sehingga Matematika menarik untuk dipelajari. Selain itu, siswa juga memberikan pendapatnya bahwa karena materi dalam Matematika diubah dalam bentuk kalimat sehari-hari, maka Matematika menjadi lebih mudah dipahami dan dimengerti.

Penggunaan komik dapat digunakan sebagai salah satu media dalam pembelajaran Matematika. Hal tersebut dapat dilakukan agar siswa tidak lagi merasa bahwa Matematika merupakan pelajaran yang membosankan maupun menakutkan karena pengemasan materi yang cenderung monoton dan buku yang digunakan berwarna hitam putih. Karena pada penelitian ini hanya terbatas pada materi aritmatika sosial, maka diharapkan untuk penelitian lain agar dapat memanfaatkan penggunaan komik dalam mengemas materi Matematika yang dianggap sulit oleh siswa. Selain itu, karena telah diketahui bahwa komik dinyatakan efektif sebagai media dalam pembelajaran Matematika, maka diharapkan untuk penelitian-penelitian selanjutnya, komik dapat digunakan dalam membantu kemampuan Matematika siswa sesuai dengan standar proses dalam NCTM, yaitu pemecahan masalah, penalaran dan pembuktian, komunikasi, representasi dan koneksi sehingga komik tidak hanya digunakan sebagai media dalam hiburan, namun juga dapat digunakan sebagai penunjang dalam pembelajaran.

\section{DAFTAR RUJUKAN}

Arini, F. D., Choiri, A. S. \& Sunardi. (2017). The Use of Comic as a Learning Aid to Improve Learning Interest of Slow Learner Student. European Journal of Special Education Research, 2(1), 71-78.

Buchori, A. \& Setyawati, R. D. (2015). Development Learning Model of Charactereducation Through E-Comic in Elementary School. International Journal of Education and Research, 3(9), 369-386.

Budiarti, W. N., \& Haryanto. (2016). Pengembangan Media Komik untuk Mengingatkan Motivasi Belajar dan Keterampilan Membaca Pemahaman Siswa Kelas IV. Jurnal Prima Edukasia, 4(2), 233-242.

Cheesman, K. (2006). Using Comics in the Science Classroom a Pedagogical Tool. Journal of College Science Teaching, 35(4), $48-51$.

Gafoor, K. A., \& Shilna, V. (2013). Role of Concept Cartoons in Chemistry Learning. Presented in Two Day National Seminar on Learning Science by Doing - Sciencing (December $5 \& 6^{\text {th }} 2013$ ) at PKM College of Education, Madampam, Kannur, India.

Graham, S. (2011). Comics in the Classroom: Something to be Taken Seriously. Language Education in Asia, $2(1), 92-102$.

Hadi, S. (2008). Pembelajaran Konsep Segiempat Menggunakan Media Pembelajaran Komik dengan Strategi Bermain Peran pada Siswa Kelas IV SD Semen Gresik. Prosiding Konferensi Nasional Matematika.

Hosler, J., \& K. B. Boomer. (2011). Are Comic Books an Effective Way to Engage Nonmajors in Learning and Appreciating Science?. CBE - Life Science Education. 10, 309-317.

Indaryati., \& Jailani. (2015). Pengembangan Media Komik Pembelajaran Matematika Meningkatkan Motivasi dan Prestasi Belajar Siswa Kelas V. Jurnal Prima Edukasia, 3(1), 84-96.

Karmawati. (2007). Penggunaan Komik dalam Pembelajaran Matematika. Jurnal Hunafa, 4(2), $121=128$.

Keogh, B., \& Naylor, S. (1999). Concept Cartoons, Teaching and Learning in Science: An Evaluation. International Journal of Science Education, 21(4), 431-446.

Manalu, M. A., Hartono, Y., \& Aisyah, N. (2017). Pengembangan Media Komik Matematika Berbasis Nilai Karakter pada Materi Trigonometri di Kelas X SMA Negeri 1 Indralaya Utara. Jurnal Elemen, 3(1), 35-48.

Mediawati, E. (2011). Pembelajaran Akuntansi Keuangan melalui Media Komik untuk Meningkatkan Prestasi Mahasiswa. Jurnal Penelitian Pendidikan, 12(1), 68-76.

Monnin, K. (2012). Teaching with Comics and Illustrated Novels: A Guide for Parents, Librarians, and Educators. Andrews McMeel Publishing.

Morrison, T.; Bryan, G. \& Chilcoat, G. (2002). Using Student-Generated Comic Books in the Classroom. Journal of Adolescent \& Adult Literacy, 45(8), 758-767.

Negara, H. S. (2014). Penggunaan Komik sebagai Media Pembelajaran terhadap Upaya Meningkatkan Minat Matematika Siswa Sekolah Dasar (SD/MI). Jurnal Pendidikan dan Pembelajaran Dasar, 1(1), 250-259.

Novianti, R. D. \& Syaichudin, M. (2010). Pengembangan Media Komik Pembelajaran Matematika untuk Meningkatkan Pemahaman Bentuk Soal Cerita Bab Pecahan pada Siswa Kelas V SDN Ngembung. Jurnal Teknologi Pendidikan, 10(1), $74-85$.

Reilly, E. M. (2014). Superheroes in Math Class: Using Comics to Teach Diversity Awareness. International Journal Work and Days, 32(1\&2), 61-74.

Rota, G., \& Izquierdo, J. (2003). "Comics" as a Tool for Teaching Biotechnology in Primary Schools. Issues in Biotechnology Teaching, 6(2), 85-89. 
Smith, A. (2006). Comics: Everything You Need to Know to Start Teaching with Comics!. Kanada: Spring.

Sudjana, N. \& Rivai, A. (2010). Media Pengajaran. Bandung: Sinar Baru Algesindo.

Sujarwo, S., \& Oktaviana, R. (2017). Pengaruh Warna terhadap Short Term Memory pada Siswa Kelas VIII SMPN 37 Palembang. Jurnal Psikologi Islami, 3(1), 33-42.

Sutrisno, I. P. W. 2016. Pengembangan Media Komik Pembelajaran pada Mata Pelajaran Matematika Materi Perpangkatan dan Penarikan Akar Bilangan Pangkat Dua dan Pangkat Tiga Sederhana Siswa Kelas V SDN Putat Jaya 5/381 Surabaya. Jurnal Mahasiswa Teknologi Pendidikan, 10(1).

Toh, T. L. (2009). Use of Cartoons and Comics to Teach Algebra in Mathematics Classrooms. National Institute of Education, Nanyang Technological University, Singapore.

Versaci, R. (2001). How Comic Books Can Change the Way Our Students See Literature: One Teachers Perspective. English Journal, 91(2), 61-67.

Waluyanto, H. D. (2005). Komik sebagai Media Komunikasi Visual Pembelajaran. Jurnal Nirmana, 7(1), 45-55.

Weiner, S. (2004). Show, Don't Tell: Graphic Novels in the Classroom. English Journal, 94(2), 114-117.

Widyastuti, P. D., Mardiyana, M., \& Saputro, D. R. S. (2017). An Instructional Media Using Comics on the Systems of Linear Equation. International Conference on Mathematics and Science Education (ISMSce).

Yunus, M. M., Saleh1, H., \& Emb1, M. A. (2012). Effects of Using Digital Comics to Improve ESL Writing. Research Journal of Applied Sciences. Engineering and Technology, 4(18), 3462-3469. 